\title{
Limits to Localism
}

\author{
Ivor Samuels \\ Honorary Senior Research Fellow, Urban Morphology Research Group, Dept of Geography, Birmingham University; \\ Tutor, Oxford University Dept. of Continuing Education. Visiting Lecturer in CRP, Spring Quarter of 2006 and 2007.
}

Europe is facing a major economic crisis that is deeply affecting the role of governments and shrinking public institutions. In England, planning has been blamed for hampering growth and economic development, and governments are turning away from reginal and long-term planning in favor of local plans and short term actions. The author discusses this pressing issue and its implications for planning.

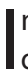
n confronting its worst economic crisis in eighty years the developed world has sought to identify the culprits of the financial turmoil, increasing unemployment and lack of growth. The most often blamed are the bankers, but in Britain the coalition government has singled out the planning profession for hampering economic growth by their bureaucratic control of development. Accordingly recent legislation has sought to introduce a planning system that in the words of a civil servant will, "persuade people to think differently about growth" and "[aspire] to decentralise power" resulting in the "abolition of regional strategies "which will be replaced by strategic planning in the context of localism" (Tyson, 2012: 17).

In practice, neighbourhood plans are being encouraged and there is a torrent of advice on how to do these. ${ }^{1}$ On the one hand very limited financial aid is being granted to a handful of pilot neighbourhood plans, while on the other hand the local government planning system, which is expected to implement the new system, is seeing a reduction of $41 \%$ in its funding, by far the harshest of any public sector cuts. The neighbourhoods have little opportunity to raise funds through local taxes to cover the costs of these plans.

Against this background of reduced funding the localism agenda is running in to several technical problems:

- While rural parishes - typically free standing villages - can conveniently form the base for defining the boundaries of some neighbourhood plans, it is much more difficult to define boundaries of neighbourhoods in urban areas of continuous development for which no tradition or inherited subdivisions exist.

- Neighbourhood plans have to agree with existing adopted local plans of the districts - so immediately their scope and freedom to change direction is limited.

\footnotetext{
${ }^{1}$ For a quick guide to neighbourhood planning, see for example: http:// www.uvns.org/sites/default/files/UVNS_Guide_to_Neighbourhood_ Planning.pdf
}

- With sub-regional housing allocations, abolished cases are being regularly reported where housing numbers are being reduced by emerging neighbourhood plans as not unexpectedly NIMBY policies predominate. Housing shortages are an issue in parts of the country under pressure for development despite the recession.

Even if adequate funding were to be made available to carry out all the other work and the neighborhoods were given the powers to raise ands spend taxes, we only have to look at the experiences of our neighbours across the channel in France to realise that even thorough-going localism has limits.

Working in France in the 1990s we had the opportunity to making several Plans d'Occupation des Sols (POS) for small settlements. These were much more than land use plans and in all cases they incorporated what in anglophone terms would be called design codes based on thorough morphological analysis of the settlements (Samuels, 1993). These towns and villages called communes, have both planning and fiscal powers and have an invigorating demonstration of localism. The Municipal Council (an elected body for a settlement of 2,500 people) would meet to make a decision so that the following day the communal public works department (with a total strength of three) would go out and change the road signs on those streets under local control.

However the big defect with this system is that our lives are not constrained within the medieval boundaries of parishes or communes. In recognition of this reality but with little success, for the last three decades France has been trying to assemble larger units for plan making - just the opposite to what seems to be happening now in the UK. Certainly in France, a country with 37,000 communes i.e. planning authorities, this problem is more acute than in England. Three decades of effort to amalgamate communes has been met with mixed success (Cahiers Francais, 2011). Their fiscal and some other responsibilities have been amalgamated into 2,599 Etablissments publics de coopération intercommunale (EPCI), or public establishments for inter-commune cooperation. In order to provide a degree 
of planning strategy, which meets the way contemporary housing and labour markets work, the French introduced a voluntary planning scheme for groups of communes in the year 2000. The Schéma de Cohérence Territoriale (SCOT), or scheme of territorial coherence, usually covers the conurbation around a large or medium sized city or, in more sparsely populated areas, linked networks of settlements.

Before its practical, if not virtual extinction, the UK's Commission for Architecture and the Built Environment (CABE) recognised the same problem. "People are travelling much further nowadays in their daily lives, which means that the way in which we plan and design our towns and cities and rural areas will need to change" (www.cabe.org.uk/large-scale-urban-design, 2011). It invested considerable resources in investigating possible solutions to what was initially called Strategic Urban Design (StrUD). The results of this work, which had begun to show some interesting direction and even question some conventional urban design wisdom, have been entombed in the national archive under the title Large Scale Urban Design - presumably StrUD sounded too much like an Early English expletive.

In its work CABE used a number of case studies ranging from Cambridge Futures via the Emscher Landschaffspark and the Jeddah Strategic Framework, to demonstrate a range of solutions to the challenge of large-scale urban design. Among those selected was the SCOT for Montpellier. This plan, which covers 31 communes, centred on the city of Montpellier and addresses strategic decisions that are conurbation-wide for such matters as the protection of the natural environment through specific boundaries to urban development.

However, a glance at any plan included in the Montpellier SCOT reveals that a large area to the southeast is omitted from consideration. For example, the plan in Figure 1 not only shows this gap in the coverage but also that a short length of Mediterranean coast has been included in the SCOT. Planning officers responsible for the work revealed that six communes had withdrawn in 2004 from the SCOT two years after the initial boundaries had been established. It was suggested that this democratic decision was the result of reluctance on the part of these relativity wealthy communes to share their tax base with the rest of the conurbation. It seems that to omit the plan communes that include a large portion of coastline, considering the environmental management issues and an international airport, really begs to question the efficacy of the SCOT.

This story clearly demonstrates how local democratic planning without a higher level of effective planning can frustrate any attempt to resolve larger scale issues.

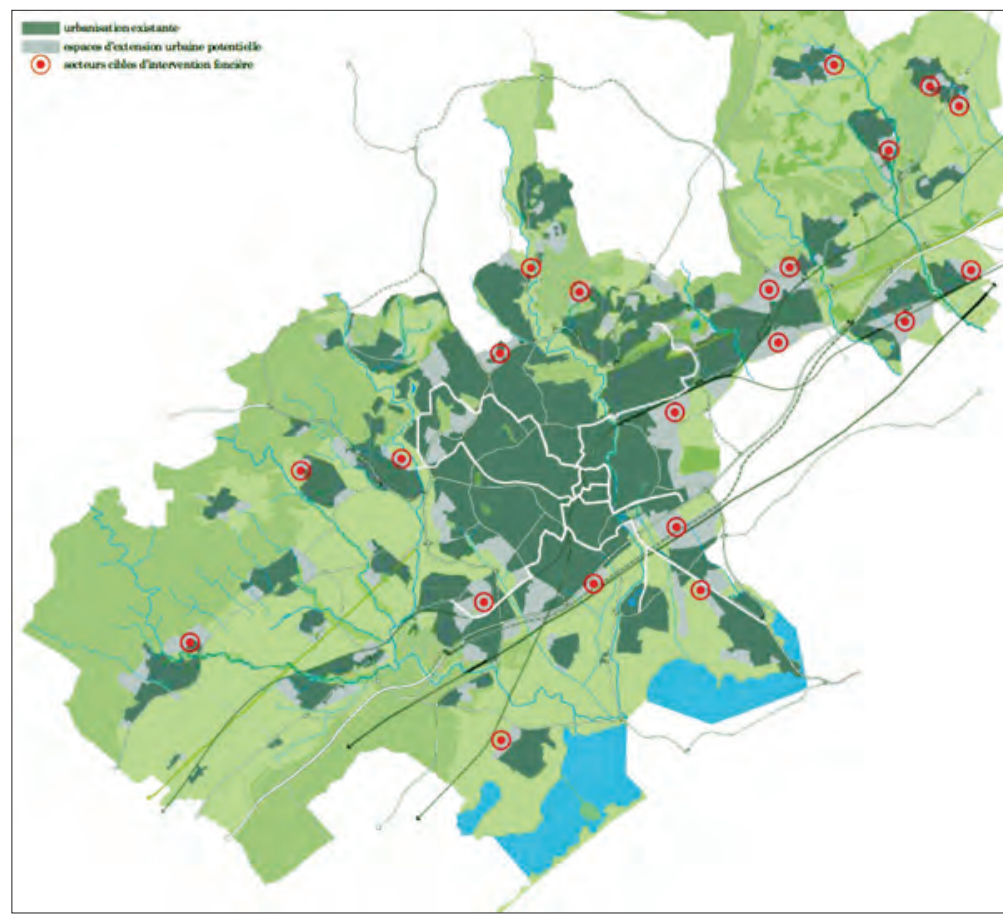

Figure 1: Montpellier SCOT. Limits to the expansion of built up areas.

\section{References}

La Documentation française. 2011. Cahiers Français 362: Les collectivités territoriales: 30 ans de décentralisation.

Tyson,T. 2012. Whitehall inanities bode ill for policy. Planning, 17 (March 9).

Samuels, I. 1993. The Plan d'Occupation des Sols for Asnieres sur Oise; a Morphological Design Guide. In Hayward, R. and McGlynn, S. (eds), Making Better Places: Urban Design Now. Oxford: Butterworth.

Montpellier Agglomeration. 2012. Le Schéma de Cohérence Territoriale (SCOT). In www.montpellier-agglo.com/nos-grands-projets/ schema-coherence-territoriale; retrieved 21 November 2011.

The National Archives, Commission for Architecture and Built Environment. 2011. In webarchive.nationalarchives.gov. uk/20110118095356/http://www.cabe.org.uk/strud/examples/montpellier; retrieved 21 November 2011.

Urban Vision, Quick Guide to Neighbourhood Planning (2012). Inwww.uvns.org/sites/default/files/UVNS_Guide_to_Neighbourhood_Planning.pdf; retrieved 21 November 2011. 